\title{
RADIATA PINE pH AND BUFFERING CAPACITY: EFFECT OF AGE AND LOCATION IN THE STEM
}

Vicente Hernández ${ }^{I}$

\begin{abstract}
In this work the effect of age and location within the stem on $\mathrm{pH}$ and buffering capacity of radiata pine sapwood was investigated. Mature and juvenile wood samples from three different heights in the trunk were obtained from 20,25, and 30 year-old trees. Aqueous wood extracts from the samples were used to determine the $\mathrm{pH}$ and buffering capacity of wood. Results show a significant effect of age and location in the tree, although a strong interaction among all factors was also detected. In general sapwood tended to be more acidic in the lower part of trees, but juvenile wood showed to be more acidic than mature wood. From both type of wood tested, juvenile wood was more sensitive to change its $\mathrm{pH}$ and buffering capacity with the height and age. The effect of wood $\mathrm{pH}$ and buffering capacity in the manufacture of wood composites is discussed and further research is recommended to determine whether the variations detected in this study can affect the curing of resins and quality of wood base composite manufactured with radiata pine wood.
\end{abstract}

Keywords: Acidity of wood, pH, buffering capacity, acid, alkali, radiata pine, age, height, juvenile wood, mature wood.

\section{INTRODUCTION}

The $\mathrm{pH}$ and buffering capacity of wood can affect a number of processes related to its utilization. For example, excessively acidic wood can produce corrosion of fasteners and nails used at wooden constructions, affect the fixation of preservative salts in wood preservation, and increase the consumption of Kraft liquor in wood pulping (Gray 1958, Sandermann and Rothkamm 1959, Sinthole 2005). The effect of wood $\mathrm{pH}$ and buffering capacity has also been extensively studied in wood composite manufacture because of its effect on the curing of resins (Bulian and Graystone 2009, Johns and Niazi 1981, Pappas et al. 1999). For example, urea-formaldehyde (UF) can decrease their gelation time when in contact with excessively acidic wood (Johns and Niazi 1981, Rayner 1965). Similarly, the curing of phenol formaldehyde resins is negatively affected by wood with high alkaline buffering capacity (Roffael and Rauch 1974).

Problems related to the curing of resins are not only reduced to the processing of extremely acidic wood. The compositing of wood with different acidities and buffering capacities may require the adjustment of hardener and buffer agents added to the resin in order to achieve an appropriate curing (Irle and Barbu 2010). Therefore, determining the variability of $\mathrm{pH}$ and buffering capacity in wood species used for composite manufacture appear to be important, especially considering that there is evidence showing that these properties can change significantly in trees of the same specie harvested at different ages and sites, and even more within wood samples obtained from different locations within the same trees (Campbell et al. 1990, Dix and Roffael 1995). 
In this work the objective was to determine the variation of $\mathrm{pH}$ and buffering capacity with the age and location in the stem in radiata pine (Pinus radiata D. Don) sapwood. Radiata pine is extensively used in plywood, particleboard and fiberboard manufacture. Hence, determining its $\mathrm{pH}$ and buffering capacity can yield results useful for detecting levels of acidity that could be problematic for its processing. $\mathrm{pH}$ and buffering capacity were measured in juvenile and mature sapwood samples, obtained from 20, 25 and 30 year-old trees at three different heights in the stem.

\section{MATERIALS AND METHODS}

\section{Experimental setup}

A completely randomized design was implemented to examine the effect of tree age, stem height and type of wood on $\mathrm{pH}$ and buffering capacity, acid and alkaline of radiata pine sapwood. Analysis of variance was used to determine significant differences among fixed factors and interactions. Statistical computation was performed using Design Expert 6.0 (Stat-ease 1997).

\section{Wood material}

Radiata pine trees were collected from plantations located in the area between $37^{\circ} 03^{\prime} \mathrm{S}$ and $37^{\circ} 35^{\prime} \mathrm{S}$; at the central valley of the "Region del Bio-Bio" in Chile. 20, 25 and 30 year-old trees ( 5 of each age) were used to obtain 90 wood samples for $\mathrm{pH}$ and buffering capacity determinations. After harvesting, 3 disks of $100 \mathrm{~mm}$ thickness were sliced from each log at 3 pre-determined heights measured from the bottom to the top of the tree. H1: height at the breast diameter; H2: $25 \%$ of usable height; and H3: $75 \%$ of usable height. The disks were then cut along the radial section and a $30 \mathrm{~mm}$ width sub-sample was extracted for sapwood-heartwood determination and annual ring counting. Sapwood-heartwood annual rings were visualized by staining the sub-samples with ferric chloride $10 \%$ solution; after 10 minutes, dark coloration revealed the presence of heartwood. Subsequently, juvenile and mature wood were segregated. Juvenile wood was considered to be the fraction within the first 10 annual rings counted from the pith to the bark, heartwood rings were discarded. Mature wood was considered from ring 11 ahead (outwards). Each type of wood was chipped manually using hammer and chisel and air dried until equilibrium moisture content (approx. 19\%). Chips were daily scrambled for an even drying and examined for presence of biological contamination, such as blue stain and mould. Contaminated chips were discarded. After drying, chips, properly labelled, were grounded in a Reichmann SM 2000 mill and screened in a Fristch 6580 sieve system. Ground wood particles retained between 60 and 40 mesh screens were stored at room temperature, in a dry environment, inside sealed polypropylene bags until $\mathrm{pH}$ and buffering capacity determinations. Measurement of $\mathrm{pH}$ and buffering capacity were accomplished approximately within 12 months from samples collection.

\section{The $\mathrm{pH}$ and buffering capacity determinations}

The $\mathrm{pH}$ and buffering capacity were determined using the method proposed by Johns and Niazi (1981). Aqueous wood extract solutions were prepared by refluxing 25 grams of ground wood at 100 ${ }^{\circ} \mathrm{C}$ for 20 minutes. After extraction aqueous solutions were filtered and stored in sealed Erlenmeyer flasks, measurements were performed within the next 24 hours after extraction using a digital $\mathrm{pH}$ meter HANNA model HI $9025 \mathrm{C}$. For pH and acid buffering capacity measurements, $60 \mathrm{ml}$ of aqueous solution was analyzed at $20{ }^{\circ} \mathrm{C}$. Afterwards, the aqueous solution was titrated to $\mathrm{pH} 3$ with $\mathrm{HCl}$ $0.025 \mathrm{~N}$. Then, a new beaker with another $60 \mathrm{ml}$ of the original aqueous solution was prepared for a second reading of $\mathrm{pH}$ and then titrated to $\mathrm{pH} 7$ with $0.025 \mathrm{~N} \mathrm{NaOH}$ for alkaline buffering capacity measurement. 


\section{RESULTS}

The $\mathrm{pH}$ values for radiata pine sapwood ranged from 4.08 to 5.45 for 20 year-old trees, 4.12 to 5.25 for 25 year-old trees, and from 3.83 to 5.70 for 30 year-old trees. Acid buffering capacity values were in a range of 0.40 to $3.60 \mathrm{ml}$ for 20 year-old trees, 0.60 to $12.70 \mathrm{ml}$ for 25 year-old trees, and 0.30 to $16.40 \mathrm{ml}$ for 30 year-old trees; and alkaline buffering capacity ranged from 3.00 to $6.91 \mathrm{ml}$ for 20 year-old trees, 2.30 to $6.80 \mathrm{ml}$ for 25 year-old trees, and 2.20 to $6.50 \mathrm{ml}$ for 30 year-old trees.

Analysis of variance detected significant changes ( $\mathrm{p}$-value $<0.001$ ) on $\mathrm{pH}$ and buffering capacity (acid and alkaline) among the different types of wood, heights and ages tested, as well as for the interactions of such factors (data not shown).

The $\mathrm{pH}$ determinations (Figure 1a) show that mature wood of $\mathrm{H} 1, \mathrm{H} 2$ and $\mathrm{H} 3$ increased its $\mathrm{pH}$ significantly only from 20 to 25 years. Conversely, juvenile wood from the three heights decreased its $\mathrm{pH}$ from 20 to 25 years. Thereafter, only $\mathrm{H} 3$ continued such tendency. At 20 years, $\mathrm{pH}$ of mature wood did not change significantly from $\mathrm{H} 1$ to $\mathrm{H} 2$, but increased at $\mathrm{H} 3$. Juvenile wood decreased its $\mathrm{pH}$ from $\mathrm{H} 1$ to $\mathrm{H} 2$, to increase it later from $\mathrm{H} 2$ to $\mathrm{H} 3$. Juvenile wood $\mathrm{pH}$ was significantly higher than mature wood only at $\mathrm{H} 1$. At 25 years, mature and juvenile wood showed no significant differences from $\mathrm{H} 1$ to $\mathrm{H} 2$; however, at $\mathrm{H} 3$ both types of wood increased significantly their $\mathrm{pH}$. Mature wood exhibited significantly higher $\mathrm{pH}$ than juvenile wood at the three heights. At 30 years, mature wood showed virtually no differences in $\mathrm{pH}$ among the three heights, but juvenile wood constantly increased its $\mathrm{pH}$ from $\mathrm{H} 1$ to $\mathrm{H} 3$. Mature wood $\mathrm{pH}$ showed significantly higher values than juvenile wood at the three heights.

Acid buffering capacity results (Figure 1b) indicate that mature wood of heights H1, H2 and H3 did not show significant differences among 20,25 and 30 year-old trees. Conversely, juvenile wood appeared highly variable as $\mathrm{H} 1$ and $\mathrm{H} 2$ increased noticeably their acid buffering capacity from 20 to 25 years, but only $\mathrm{H} 1$ continued to increase from 25 to 30 years. H3 showed no significant changes over time. At 20 years, no significant differences between acid buffering capacity of mature and juvenile wood were detected. Also, no significant changes occurred from H1 to H3. At 25 years, mature wood continued exhibiting no significant differences among different heights. However, acid buffering capacity of juvenile wood decreased from $\mathrm{H} 1$ to H3. Significant differences between mature and juvenile wood were present at $\mathrm{H} 1$ and $\mathrm{H} 2$. At 30 years, mature and juvenile wood behaved similarly to 25 year-old; mature wood exhibited no significant differences among different heights and juvenile wood decreased significantly from $\mathrm{H} 1$ to $\mathrm{H} 3$. Again, differences between mature and juvenile wood were only verified at $\mathrm{H} 1$ and $\mathrm{H} 2$.

Alkaline buffering capacity results (Figure 1c) show that mature wood H1 and H2 increased significantly its value from 20 to 25 years, but decreased from 25 to 30 years. H3 decreased almost constantly from 20 to 30 years. Juvenile wood at the three heights also depicted an increment of alkaline buffering capacity from 20 to 25 years. However, from 25 to 30 years H1 decreased significantly. At 20 years, alkaline buffering capacity of mature wood increased significantly from $\mathrm{H} 1$ to H3. Conversely, juvenile wood decreased from $\mathrm{H} 1$ to $\mathrm{H} 3$. Significant differences between mature and juvenile wood were verified only at $\mathrm{H} 3$. At 25 years, mature wood exhibited no significant differences among heights, but juvenile wood decreased remarkably its alkaline buffering capacity value from H1 to H3. Significant differences between mature and juvenile wood were verified at $\mathrm{H} 1$ and $\mathrm{H} 2$. At 30 years, mature and juvenile wood behaved similarly to 25 years. No significant differences were verified for mature wood, and juvenile wood decreased significantly from $\mathrm{H} 1$ to $\mathrm{H} 3$. Alkaline buffering capacity values of mature and juvenile wood were significantly different at $\mathrm{H} 1$ and $\mathrm{H} 2$. 


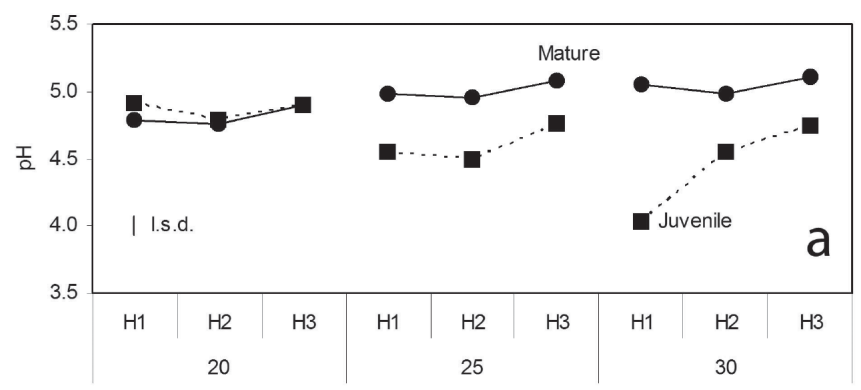

Height / Age (years)

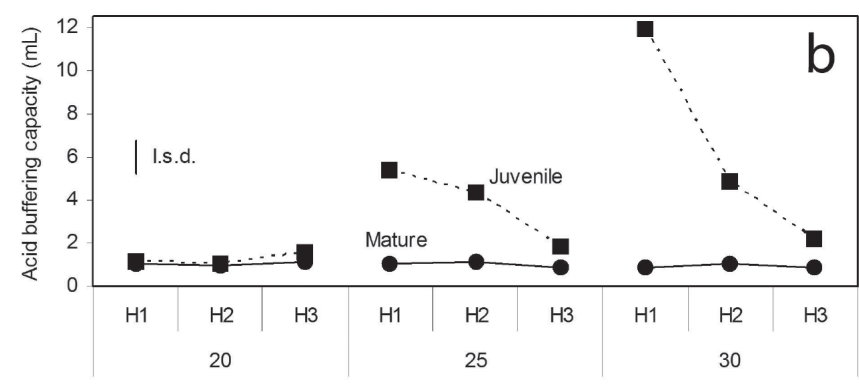

Height / Age (years)

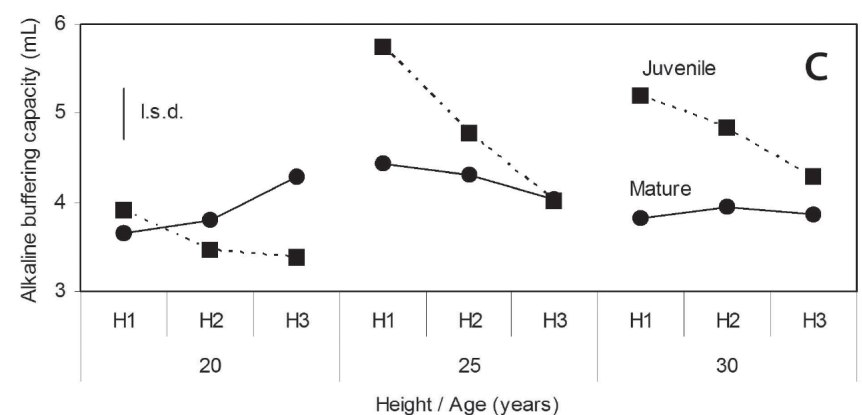

Figure 1. The $\mathrm{pH}$ and buffering capacity of juvenile and mature radiata pine sapwood samples obtained from 20, 25 and 30 year-old trees at three different heights in the stem (H1: height at the breast diameter, $\mathrm{H} 2: 25 \%$ of usable height and $\mathrm{H} 3: 75 \%$ of usable height). (a) $\mathrm{pH}$, (b) acid buffering capacity and (c) alkaline buffering capacity.

(1.s.d.) least significant difference bar 


\section{DISCUSSION}

In this experiment significant variations on $\mathrm{pH}$ and buffering capacity were verified among the different ages, heights and types of wood tested. These variations might be related to changes in the distribution of salts, extractives, acidic groups in hemicelluloses and soluble and insoluble organics acids, as these substances appear responsible for the acidity of wood (Ingruber 1958, Klauditz 1957, Packman 1960). In radiata pine sapwood important sources of variation may be found in hemicelluloses and to a lesser degree in extractives and inorganic substances. The effect of the distribution of such substances can be visualized, for example, in $\mathrm{pH}$ differences between mature and juvenile wood. Chemically juvenile wood differs from mature wood in its amount of hemicelluloses and lignin (Rowell 2005). Juvenile wood has a higher content of hemicelluloses and in consequence must have higher availability of acidic groups and a higher acidity than mature wood. This tendency was verified for several juvenile wood samples during the trial. On the other hand, extractives may be more related to changes in $\mathrm{pH}$ and buffering capacity with the age. $\mathrm{pH}$ differences between trees of different ages, informed by Roffael and Rauch (1974), indicated that older trees tend to have lower $\mathrm{pH}$ and higher amount of extractives. In addition, experimentation with these substances showed that extractives of older trees have higher alkaline buffering capacity than extractives from younger trees (Roffael and Rauch 1974). Variations of pH and buffering capacity along the stem have also been associated with the presence of extractives, although in wood which contains heartwood (Sandermann and Rothkamm 1959, Campbell et al. 1990). Since in the present work heartwood was not tested it could be imprudent to attribute such variations only to extractives. More complex interaction in the stem among acidic groups from hemicelluloses, inorganic compounds and extractives might be behind the tendency of mature and juvenile to be more acidic at the lower sections of trees.

Problems related to the acidity of radiata pine have been described in particleboard manufacture. The processing of excessively acid radiata pine particles can result in boards with decreased mechanical properties because of improper resin curing (Martin 1995). When acidic species are used for composite manufacture, adhesives can precure before the board have been compressed in the hot press. The precured resin bonds break down in the hot press generating losses in mechanical properties (Irle and Barbu 2010). Wood $\mathrm{pH}$ and buffering capacity have been demonstrated to affect the curing of most widely used resins for wood composites, e.g. UF and melamine-formaldehyde (MF) resins (Bulian and Graystone 2009, Johns and Niazi 1981, Pappas et al. 1999, Roffael and Rauch 1974). Relatedly, large wood buffering capacity can interfere with the curing of UF and MF resins (Guevara and Johns 1980). A large buffering capacity can impede the reduction in $\mathrm{pH}$ which is necessary for the hardening reaction. In any situation, the fluctuation of $\mathrm{pH}$ and buffering capacity of wood are problematic because it causes variations in panel properties (Maloney 1977).

\section{CONCLUSIONS}

The variation of $\mathrm{pH}$ and buffering capacity with the age and location in stem was investigated in radiata pine sapwood. Experimental results support the hypothesis that these chemical properties can change significantly in trees of the same specie harvested at different ages and within samples extracted from different locations in the same trees.

General trends show that juvenile wood tended to be more acidic than mature wood in 25 and 30 year-old trees. Variations with the age revealed that while mature wood decreased its acidity, showing no relevant changes in its buffering capacities, juvenile wood increased both its acidity and both buffering capacities. In terms of height, mature and juvenile wood tended to be more acidic in the lower sections of the trees, but differences in buffering capacity were observed only in juvenile wood. Further research is required to determine whether the variation of $\mathrm{pH}$ and buffering capacity detected in this study can affect the quality of wood base composite manufactured with radiata pine wood. 


\section{REFERENCES}

Bulian, F.; Graystone, J. 2009. Wood coatings: Theory and practice. Amsterdam, NLD: Elsevier.

Campbell, A.; Kim, W.J.; Koch, P. 1990. Chemical variation in Lodgepole pine sapwood/heartwood, stem height, and variety. Wood and fiber science 22(1): 22-30.

Dix, B.; Roffael, E. 1995. Zum Verhalten des Splint- und Kernholzes der Lärche (Larix decidua) bei der Herstellung von feuchtebest ndigen Spanplatten unter Einsatz verschiedener Bindernittel. Holz als Roh- und Werkstoff 53(6): 357-367.

Gray, V. 1958. The acidity of wood. Journal of the Institute of Wood Science 1: 58-64.

Guevara, R.; Johns, W. 1980. Geographical and within-tree variation in heartwood $\mathrm{pH}$ of Pinus oocarpa Scheide from Honduras. The Malaysian Forester 13(4): 200-224.

Ingruber, O. 1958. The behaviour of wood and wood constituents as acid-buffering systems. Pulp and paper Canada 59(11): 135-141.

Irle, M.; Barbu, M. 2010. Wood-based panel technology. In. Wood-based panels - An introduction for specialist (Ed. Thoemen H., Irle M., and Sernek M.). London, England: Brunei University Press.

Johns, W.; Niazi, K. 1981. Effect of $\mathrm{pH}$ and buffering capacity of wood on the gelation time and urea-formaldehyde resin. Wood and fiber science 12(4): 255-263.

Klauditz, W. 1957. Zur biologisch-mechanischen Wirkung der Acetylgruppen im Festigungsgewebe der Laubhölzer. Holzforschung 11(2): 47-55.

Maloney, T. 1977. Modern particleboard and dry-process fibreboard manufacturing. San Francisco, USA: Miller Freeman Publications Inc.

Martin, A. 1995. Wood acidity in Radiata pine and its effect on particleboards (Bachelor of Science Thesis). The Australian National University, Camberra.

Packman, D. 1960. The acidity of wood. Holzforschung 14(6): 178-183.

Pappas, C.; Rodis, P.; Tarantilis, P.; Polissiou, M. 1999. Prediction of the $\mathrm{pH}$ in wood by diffuse reflectance infrared fourier transform spectroscopy. Applied spectroscopy 53(7): 805-809.

Rayner, C. 1965. Synthetic organic adhesives. In. Adhesion and adhesives (Ed. R. Houwink and G. Salomori). New York, USA: Elsevier. pp. 186-352.

Roffael, E.; Rauch, W. 1974. Extraktstoffe in Eiche und ihr Einfluß auf die Verleimbarkeit mit alkalischen Phenol-Formaldehydharzen. Holz als Roh- und Werkstoff 32(5): 182-187.

Rowell, R. 2005. Handbook of wood chemistry and wood composites. CRC Press.

Sandermann, W.; Rothkamm, M. 1959. Über die Bestimmung der pH-Werte von Handelshölzern und deren Bedeutung für die Praxis. Holz als Roh- und Werkstoff 17(11): 433-440.

Sinthole, B. 2005. New method of measuring the $\mathrm{pH}$ of wood chips. Pulp and paper Canada 106(11): 25-42.

Stat-ease. 1997. Design expert 6.0. Minneapolis, USA: Stat-ease. 